
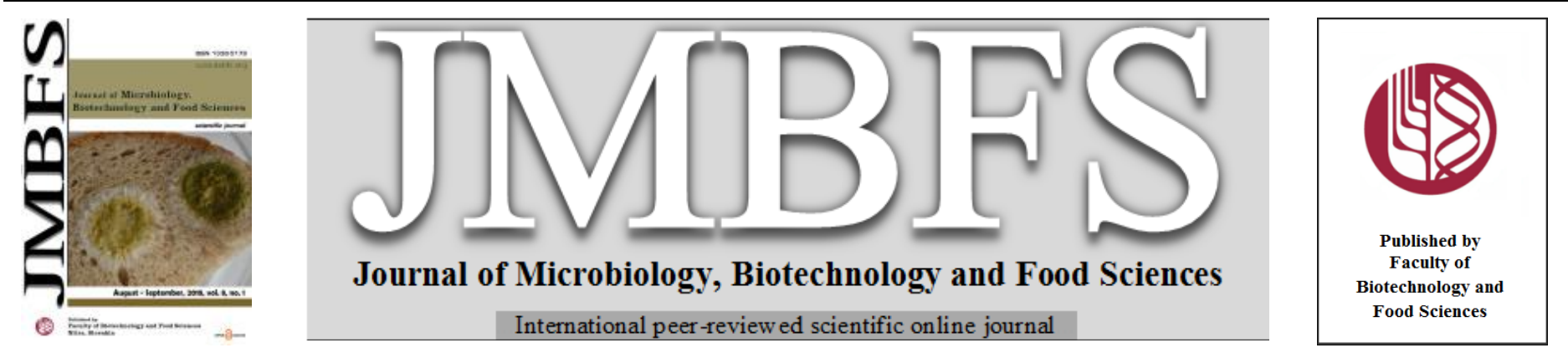

\title{
POTENTIAL OF LIQUID TOFU WASTE FOR DECAFFEINATION OF ROBUSTA COFFEE (Coffea robusta Lindl.Ex De Will)
}

\author{
Ayu Rahmawati Sulistyaningtyas ${ }^{1}$, Erma Prihastanti ${ }^{2}$, Endah Dwi Hastuti ${ }^{2}$
}

Address(es):

${ }^{1}$ University of Muhammadiyah Semarang, Faculty of Nursing and Health Sciences, Medical Laboratory Technology Study Program, Street of Kedungmundu No.18,

Semarang 50273, Indonesia.

${ }^{2}$ Diponegoro University, Faculty of Biology, Street of Prof Soedarto No. 1, Semarang 50275, Indonesia.

*Corresponding author: ayurs@unimus.ac.id

doi: 10.15414/jmbfs.2018.8.1.678-680

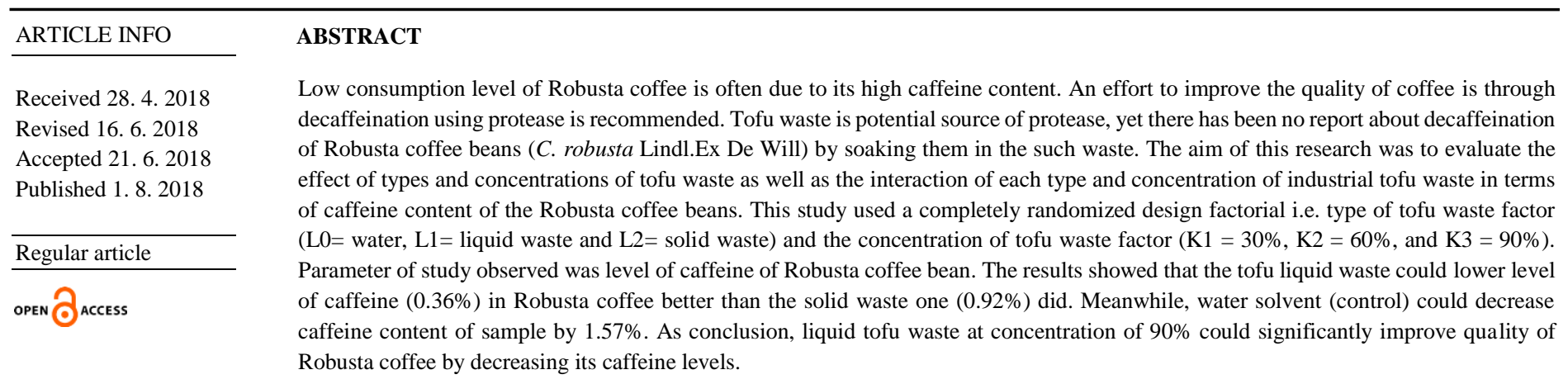

Keywords: caffeine, coffee, C. robusta, tofu, waste

\section{INTRODUCTION}

Coffee is classified in genus Coffea consisting around a hundred of species including Coffea arabica, C. robusta and C. liberica (Wang and Ho, 2009). However, of a hundred species only two types showing high economic value, i.e. C. arabica and C. robusta.

The first coffee species cultivated in Indonesia was $C$. arabica, followed by $C$. liberica and $C$. robusta, respectively. Currently, coffee plants mostly cultivated in Indonesia are Robusta coffee plants resulting $90 \%$ of the total coffee production Indonesia (Rahardjo, 2012). This is likely because Robusta type of coffee is more resistant to pests Hemelia vastatrix (HV) than other types of coffee (Rohmah, 2010). In addition, Robusta coffee has higher antioxidant activity than Arabica coffee (Richelle et al., 2001).

In Indonesia, coffee plantations began to develop rapidly making it potential for development of domestic coffee. Coffee plantations in Indonesia today reached over 1.291 million hectares, $96 \%$ of which are people's coffee plantation. Specialty coffee group produced from coffee plantations include Gayo, Mandheling, Lintong coffee, Java, Bali Kintamani, Flores, Toraja, Lampung and Luwak coffees (Kusdriana, 2011). The growing rate of coffee areas in Indonesia reached an average of 1.9 to $2.2 \%$ per year. The volume of world coffee trade in exports and imports continued to increase at an average value of $1.8 \%$ per year. These conditions is considered supportive for the development of Indonesian domestic coffee to enter the international coffee market (Rahardjo, 2012).

Requirements of quality coffee based on SNI 01-3542-2004 encompass physical, chemical and biological group of properties (Yulia et al., 2016). The physical properties include performance (odor, color and flavor), seed size, seed weight and seed hardness. The chemical properties include proximates (moisture, ash, fat, protein and carbohydrates), caffeine content, metals and other chemical compounds. The biological properties include the content of microorganism, insects and fungi contaminants.

Chemical compounds in coffee beans consist of volatile and nonvolatile compounds. Volatile compounds are compounds which evaporate especially if there is an increase in temperature. Volatile compounds affecting the aroma of coffee are groups of aldehydes, ketones and alcohols. Nonvolatile compounds affecting the quality of the coffee include caffeine, chlorogenic acid and other nutritional compounds (Johnston et al., 2003).

Caffeine is a methyl-xanthine alkaloids including 1,3,7 trimethyl xanthine. The caffeine content of $115 \mathrm{mg}$ per $10 \mathrm{~g}$ of ground coffee ( $\pm 1-2$ tablespoons) in 150 $\mathrm{ml}$ of water (Dollemore \& Giuliucci, 2001). Decreased content of caffeine in coffee is needed to limit caffeine consumption which is safe at doses of 100-200 mg per day (Sera et al., 2013). Robusta coffee beans contain $2 \%$ caffeine whereas the minimum levels of caffeine in coffee is $0.3 \%$ (Widyotomo et al., 2009). Research by Bonita et al., (2007) showed that caffeine could act as antiinflammatory in humans, thus beneficial for heart health. Excess limit in consuming caffeine will cause negative effects, such as insomnia interfering with normal metabolic cycle (Tello et al., 2001).

One of the diversification of coffee products is coffee decaffeination Decaffeination is an effort to lower the levels of caffeine in coffee to produce coffee decaffeination (De Azevedo et al., 2008). Obstacles in producing of decaffeination coffee products in Indonesia are due to unpublished rules including patents covering design, methods and characteristics of the process, and the quality of the final product decaffeination industrial scale coffee unpublished (Widyotomo et al., 2012). Decaffeination could be done using various methods including physical, chemical and biological. For example, the type of method, which has been used is using water (water decaffeination), solvents (solvent decaffeination) and super critical $\mathrm{CO}_{2}$ (carbon dioxide decaffeination). Decaffeination using water is also known as the Swiss water process because it was first performed in the country Switzerland. Advantages of this method include a readily available, relatively inexpensive and safe for health. Weakness decaffeination is using solvent water is lost flavor to the coffee produced.

During this time, many developed countries are importing domestic coffee Indonesia later after going through the process will be marketed decaffeination back in Indonesia in coffee packaging decaffeination. This causes the price of coffee decaffeination expensive in Indonesia. Several studies have been conducted, among others, the development decaffeination Robusta coffee beans in a reactor single column using the solvent water (Mulato, 2001; Lestari, 2004), decaffeination coffee solvent ethyl acetate technical concentration of $10 \%$ (Purwadaria et al., 2007; Widyotomo et al., 2009) and the use of organic solvents 
such as bromelain from pineapple to reduce levels of caffeine (Oktadina $\boldsymbol{e t}$ al, 2013).

Decaffeination by conventional fermentation involves the use of civet or luwak animal. The principle of decaffeination in civet digestion involves the breakdown of protein by protease enzyme (Hadipernata \& Nugraha, 2012). Luwak coffee is known as the most expensive coffee in the world, worth $\$ 70$ up to $\$ 425$ per half kilogram (Kusdriana, 2011). The availability of luwak coffee is limited in the market leading to high cost. In addition to civet coffee, another decaffeinated coffee could be generated by soaking the coffee in pineapple. Triyana (2014) reported that immersion of coffee in pineapple fruit pulp extract could result in a decrease in caffeine and improvement of coffee quality and taste of the resulting coffee is better than that after soaking in water. If Indonesian domestic coffee could be processed into decaffeinated coffee products with a simple method referring to the principle of protease decaffeination, then its production costs could be lowered This study is expected to find a way to increase the value of domestic coffee, so it can compete with coffee products from other countries.

Decaffeination of coffee could be done using protein-rich wastes, which could potentially act as an organic solvent containing protease. One of them knownto be generated in large amount, but has not handled correctly is tofu waste. Tofu industry is part of home industry sector commonly found in Indonesia because it could absorb labor force in large quantities. However, there is still much limitation to handle this waste (Salim $\boldsymbol{\&}$ Sriharti, 2004). Tofu wastes are generally divided into two forms, the solid waste and the liquid one. The expansion of tofu industry caused growing amount of produced waste. If the tofu waste is directly discharged into river, it will result in declining water quality and lowering environmenta capacity of waters around tofu industry because its characteristics still exceeds the quality of waste water (Puspayana \& Damayanti, 2013).

The utilization of tofu waste could be seen in the making of tofu residue ketchup, tofu flour, tofu residue flakes and latex as well as animal feed (Matthew $\boldsymbol{\&}$ Sinurat, 2001;Brownstone, 2004). Tofu wastes are known to contain still high protein with the protease in it (Living Environment Government, 2006). Such proteases are naturally produced by microorganisms in tofu waste have proteolytic activity hugher than activity of bromelain extracted from pineapple (Rahman \& Indarto, 2013)

Poedjiadi (2006) reported that work of enzyme is influenced by several factor including enzyme concentration, substrate concentration, temperature, $\mathrm{pH}$ and inhibitors. The rate of reaction increases following the increasing concentrations of the enzyme. The transfer process of caffeine from coffee bean to solvent occurs due to the driving force in the form of differences in solubility of the compound concentration and caffeine found in coffee beans with a solvent (Earle $\boldsymbol{e t}$ al. 1983). Driving force affects the speed of caffeine breakdown by enzymes. The higher the concentration of the solvent, the more rapid will be the transfer process (Mulato, 2001; Lestari, 2004; Widyotomo et al., 2009). Therefore, the concentration of tofu waste used in coffee soaking is directly related to the concentration of the enzyme contained therein which would affect the content of caffeine in coffee Robusta. The purpose of this study was to assess the effect of interaction of types and concentrations of tofu waste affecting levels of caffeine of the Robusta coffee (C. robusta Lindl.Ex De Will) as well as to determine the potential of tofu waste as a solvent in decaffeination process of Robusta coffee.

\section{MATERIAL AND METHODS}

\section{Preparation of Coffee Sample}

Ripe coffee fruit was taken from robusta coffee plantation in Ambarawa, Centra Java. Coffee fruit was harvested by plucked, typically are ripe coffee cherries, red in color with the same size and without physical defects. Coffee cherries were picked and stored at low temperatures. After that, the coffee fruitswere peeled, so coffee beans with parchment skin were obtained. Weighing of coffee beans done before treatment.

\section{Preparation of TofuWaste}

Tofu waste obtained from a home industry of tofu in Magelang, Central Java. Tofu waste used in this study was that in the form of liquids and solids. Period of treatment should be not more than $12 \mathrm{~h}$ after being collected because after $12 \mathrm{~h}$, the tofu waste will stink. Both solid and liquid wastes were measured up to a volume of $100 \mathrm{~mL}$.

\section{Calculation of Caffeine Content}

\section{Preparation of caffeine solution standard $(1000 \mathrm{mg} / \mathrm{L})$}

As much as $250 \mathrm{mg}$ of caffeine was weighed and then put in a beaker. After that caffeine was diluted in hot distilled water. The solution was diluted with distilled water in a flask so that its volume reached $250 \mathrm{~mL}$ and then homogenized pins. As much as $15 \mathrm{~mL}$ of this solution was transferred intoa flask and then diluted with distilled water to reach $25 \mathrm{ml}$ total volume, and then homogenized.
The absorbance of the standard solution was measured in the wavelength range of 250-300 nm using a UV-Vis spectrophotometer instrument. Furthermore, the standard curve that connecting relationship of absorbance Vs concentration of standard solution was created.

\section{Preparation of Standard Curve}

The preparation the standard solution was initiated by preparing a stock solution at concentration of $1000 \mathrm{mg} / \mathrm{L}$. A dilution series was then made by pipetting following the following amount of $0.05 ; 0.1 ; 0.15 ; 0.2 ; 0.25 ; 0.25$; and $0.3 \mathrm{ml}$ of $2.5 \mathrm{~mL} / 25 \mathrm{~mL}$ standard solution, which was made from $1000 \mathrm{mg} .1^{-1}$ solution, into a container where then distilled water was added to each of pipetted solution to reach total volume of $5 \mathrm{~mL}$. The concentration of the obtained solutions obtained from the dilution series were $1 ; 2 ; 3 ; 4 ; 5 ; 6 ; 7 ; 8 \mathrm{mg} .1^{-1}$, respectively. Extraction for the determination of caffeine in each obtained solution was carried out similar with that in sample (step 5). After that, absorbance of each standard solution concentration was measured. Next, based on the obtained data, standard curve equation was set using Least Square method.

\section{Qualitative Test samples}

Each of samples qualitatively tested were dissolved in alcohol, then the Parry reagent and a few drops of dilute ammonia were added. Samples containing caffeine was characterized by the formation of a dark blue/ green.

\section{Determination of Caffeine Levels of Samples}

A total of $1 \pm 0.0001 \mathrm{~g}$ of sample was put in a beaker glass, then $150 \mathrm{~mL}$ of hot distilled water was added and then stirred. The obtained solution was then filtered with filter paper and the filtrate was transferred into Erlenmeyer. As much as 1.5 $\mathrm{g}$ of Calcium Carbonate $\left(\mathrm{CaCO}_{3}\right)$ was added to the Erlenmeyer, and then the obtained solution was transferred to a separating funnel and subjected to extraction using $25 \mathrm{ml}$ of chloroform for 4 times. The bottom layer of mixture in separating tunnel was isolated and placed in a rotary evaporator so that all the chloroform evaporated. The obtained caffeine-free solvent extract was added to a 100 -flask, and then diluted with distilled water up to the mark and later homogenized. The absorbance of the homogenous solution of each sample was then measured at 275 $\mathrm{nm}$. Caffeine content was finally determined using the previously set standard curve equation.

\section{RESULTS AND DISCUSSION}

Today, low caffeine (decaffeinated) coffee has been the center of attention of producers and consumers of coffee all around the world. Thus, efforts to diversify coffee products through decaffeination have become widely developed. A way of coffee decaffeination is by using protease. A decaffeination method could be developed by utilizing wastes which could act as an organic solvent containing protease. Tofu waste could be a promising source of protease. Decaffeination of coffee by utilizing tofu waste has not been reported, so experiments to evaluate potential of tofu waste for coffee decaffeination as well as the determination of the most optimal soaking time for the decaffeination process is important to do.

Table 1 Average of Caffeine Content after Soaking in Tofu Waste

\begin{tabular}{lcccc}
\hline \multirow{2}{*}{$\begin{array}{l}\text { Concentration } \\
\text { of solvent }\end{array}$} & \multicolumn{4}{l}{ Level of Caffeine \% } \\
\cline { 2 - 5 } & Before soaking & $\begin{array}{c}\text { In water } \\
\left(\mathrm{L}_{0}\right)\end{array}$ & $\begin{array}{c}\text { In solid } \\
\text { waste }\left(\mathrm{L}_{1}\right)\end{array}$ & In liquid waste $\left(\mathrm{L}_{2}\right)$ \\
\hline $\mathrm{K}_{1}(30 \%)$ & 1.78 & 1.60 & 1.45 & 0.77 \\
\hline $\mathrm{K}_{2}(60 \%)$ & 1.82 & 1.66 & 1.19 & 0.47 \\
\hline $\mathrm{K}_{3}(90 \%)$ & 1.75 & 1.57 & 0.92 & 0.36 \\
\hline
\end{tabular}

The results of this study (Table 1) showed that robusta coffee beans (C. robusta Lindl. Ex De Will) soaked in solid and liquid tofu waste have lower levels of caffeine. Variation of tofu waste concentration significantly affected the decreased level of caffeine. The higher the concentration of the solvent, the more rapid will be the transfer process of caffeine compounds (Mulato, 2001; Lestari, 2004; Widyotomo et al., 2009). The caffeine levels of Robusta coffee beans before soaking were in a range of $1.82 \%-1.75 \%$. The caffeine levels of Robusta coffee beans after soaking were in a range of $1.66 \%-0.36 \%$. This suggests that the caffeine content of Robusta coffee still meet the standards stated by SNI 01-35422004 rule, i.e. 2\% (Yulia et al., 2016). Low-caffeine coffee is considered a coffee product alternative safer for consumers. Ky et al., (2011) stated that the safe limit consumption of caffeine in coffee is $0.3 \%$. Robusta coffee treated by soaking it in $90 \%$ liquid tofu waste could yield a decreased caffeine level by $0.36 \%$ making it meet safe limits of consumption. According with Smith et al., (2006), the exceeding the limit consumption of caffeine consumption could lead to chronic insomnia, increases heart rate and an increased risk of cholesterol build up. Robusta coffee beans used in this study were in the form of green beans, so that their skin surface horn still had mucus layer. Fermentation of these beans will 
degrade the mucus layer on the surface of the beans. Also, this mucus layer could be degraded by enzymes released by microorganisms. Tofu waste contain microorganisms producing protease (Wardani \& Nindita, 2012). Proteases released by microorganisms will hydrolyze caffeine into 7 methyl-xanthine, which later could be broken down back into xanthine. The formed xanthine will be simplified into urea so that the $\mathrm{NH}_{2}$ group could be utilized by microorganisms as a source of nitrogen (Mulato, 2001). The enzyme concentration will increase the speed of reaction (Poedjiadi, 2006). After the mucus layer is degraded by a protease, the beans will continuously be fermented to its cytoplasm, which then hydrolyzes caffeine. Caffeine present in the cytoplasm is in its free state (Ridwansyah, 2003). These conditions allow caffeine to easily move and diffuse out through the cell wall. The enzyme activity is influenced by the type and concentration of the tofu waste. The greater the concentration of waste out is used, the greater the fall in the levels of caffeine in coffee. In this study, the measurement of absorbance both for standard solution and sample of caffeine was carried out using UV spectrophotometer with $\lambda$ ranging from $250-300 \mathrm{~nm}$ because the colorless liquid absorbed the highest in this range of wavelength. As a reference, colorless DNA isolate also absorb within this range, best at $260 \mathrm{~nm}$ (Ethica et al., 2017).

Soaking the beans in both solid and liquid tofu waste could break down the mucus layer. Decay of mucus layer on the surface of the beans causes the water to easily go into the seed. The occurrence of water entering into the seed is called osmosis, which happens due to differences of water concentration, where water concentration outside the coffee beans is higher than that inside the coffee beans Caffeine is a substance with water-soluble properties (Muchtadi, 2010). Tofu waste still contain water and thus potentially capable of dissolving the caffeine. Immersion of coffee beans in liquid tofu waste could lower the caffeine level coffee beans more than that in solid tofu waste. This is due to water content in the tofu waste is higher than that in the solid one. The incoming water will cause caffeine to become compounds with smaller molecular weight and subsequently dissolved along the water (Mulato, 2001).

\section{CONCLUSION}

Robusta coffee beans (C. robusta Lindl. Ex De Will) soaked in liquid tofu waste at $90 \%$ concentration has the lowest content of caffeine and chlorogenic acid compared to those at lower concentrations. This shows potential benefit of tofu waste to be used as a solvent in the decaffeination of robusta coffee (C. robusta Lindl. Ex De Will)

\section{REFERENCES}

Ashihara, H., Sano, H., \& Crozier, A. (2008). Caffeine and related purine alkaloids: biosynthesis, catabolism, function and genetic engineering. Phytochemistry, 69(4), 841-856.https://doi.org/10.1016/j.phytochem.2007.10.029

Brownstone, M.(2004). Pemanfaatan Limbah Cair Pabrik Tahu Sebagai Penggumpal Lateks. Jurnal Sains Kimia, 8(1), 26-28.

De Azevedo, A. B. A., Mazzafera, P., Mohamed, R. S., Melo, S. A. B., \& Kieckbusch, T. G. (2008). Extraction of caffeine, chlorogenic acids and lipids from green coffee beans using supercritical carbon dioxide and co-solvents. Brazilian Journal of Chemical Engineering, 25(3), 543552.http://dx.doi.org/10.1590/S010466322008000300012

Badan Pengawas Obat dan Makanan Republik Indonesia. 2004. Acuan Sediaan Herbal, Departemen Kesehatan, 4(1). Jakarta.

Dollemore, D., \& Giuliucci, M. (2001). Rahasia Awet Muda bagi Pria. Jakarta: PT Gramedia Pustaka Utama.

Earle, R. L. (2013). Unit operations in food processing. Elsevier. ISBN:008025537-X

Ethica, S. N., Semiarti, E., Widada, J., Oedjijono, O., \& Joko Raharjo, T. (2017) Characterization of moaC and a nontarget gene fragments of food-borne pathogen Alcaligenes sp. JG3 using degenerate colony and arbitrary PCRs. Journal of Food Safety. https://doi.og/10.1111/jfs. 12345

Hadipernata, M., \& Nugraha, S. Identifikasi Fisik, K. (2012). Mikrobiologi Biji Kopi Luwak sebagai Acuan Teknologi Proses Kopi Luwak Artifical. In Prosiding Seminar Nasional Intensif Riset Sinas (pp. 117-121).

Johnston, K. L., Clifford, M. N., \& Morgan, L. M. (2003). Coffee acutely modifies gastrointestinal hormone secretion and glucose tolerance in humans: glycemic effects of chlorogenic acid and caffeine. The American journal of clinical nutrition, 78(4), 728-733.

Kusdriana, D. (2011). Peluang dan Tantangan Industri Kopi Indonesia Dalam Persaingan Pasar Global. Jakarta: PT. Media Data Riset.

Ky, C. L., Louarn, J., Dussert, S., Guyot, B., Hamon, S., \& Noirot, M. (2001) Caffeine, trigonelline, chlorogenic acids and sucrose diversity in wild Coffea arabica L. and C. canephora P. accessions. Food chemistry, 75(2), 223-230. https://doi.org/10.1016/S0308-8146(01)00204-7

Lestari, H. (2004). Dekafeinasi biji kopi (Coffee canephora) varietas robusta dengan sistem pengukusan dan pelarutan (Doctoral dissertation, Tesis. Program pascasarjana. Universitas Gadjah Mada. Yogyakarta).

Muchtadi, T. R., \& Ayustaningwarno, F. (2010). Teknologi proses pengolahan pangan. Bogor: Alfabeta.
Mulato, S. (2001). Pelarutan Kafein Biji Robusta Dengan Kolom Tetap Menggunakan Pelarut Air. Jakarta: Pelita Perkebunan.

Oktadina, F. D., Argo, B. D., \& Hermanto, M. B. (2013). Pemanfaatan Nanas (Ananas Comosus L. Merr) untuk Penurunan Kadar Kafein dan Perbaikan Citarasa Kopi (Coffea Sp) dalam Pembuatan Kopi Bubuk. Jurnal Keteknikan Pertanian Tropis dan Biosistem, 1(3).

Poedjiadi, A. (2006). Dasar-dasar Biokimia. Jakarta: UI Press.

Sera, T., Soccol, C. R., Pandey, A., \& Roussos, S. (Eds.). (2013). Coffee Biotechnology and Quality: Proceedings of the 3rd International Seminar on Biotechnology in the Coffee Agro-Industry, Londrina, Brazil. Springer Science \& Business Media.

Purwadaria, H. K., Syarief, A. M., \& Mulatno, S. (2007). Dekafeinasi Kopi dalam Reaktor Kolom Tunggal dengan Pelarut Tersier dari Pulpa Kakao.

Puspayana, D. R., \& Damayanti, A. (2013). Pengolahan Limbah Cair Tahu Menggunakan Membran Nanofiltrasi Silika Aliran Cross Flow untuk Menurunakan Kadar Nitrat dan Amonium. Jurnal Teknik ITS, 2(2), D87-D91.

Rahardjo, P. (2012). Panduan Budidaya dan Pengolahan Kopi Arabika dan Robusta. Penebar Swadaya. Jakarta.

Rahman, A., \& Indarto, C. (2013). Aktivitas Proteolitik Mikroorganisme Limbah Padat Pengolahan Tahu.

Richelle, M., Tavazzi, I., \& Offord, E. (2001). Comparison of the antioxidant activity of commonly consumed polyphenolic beverages (coffee, cocoa, and tea) prepared per cup serving. Journal of Agricultural and Food Chemistry, 49(7), 3438-3442. https://doi.org/10.1021/jf0101410

Ridwansyah. (2003). Pengolahan Kopi. Fakultas Pertanian Universitas Sumatera Utara.

Rohmah, M. (2010). Aktifitas antioksidan campuran kopi robusta Coffea cannephora dengan kayu manis Cinnamomum burmanii. Jurnal Teknologi Pertanian, 6(2).

Smith, B. D., Gupta, U., \& Gupta, B. S. (Eds.). (2006). Caffeine and activation theory: effects on health and behavior. CRC Press.

Salim, T., \& Sriharti, S. (2004). Teknologi Penanganan Limbah Cair Tahu Subang: UPT Balai Pengembangan Teknologi Tepat

Tello, J., Viguera, M., \& Calvo, L. (2011). Extraction of caffeine from Robusta coffee (Coffea canephora var. Robusta) husks using supercritical carbon dioxide. The Journal of Supercritical Fluids, 59, 53 60.https://doi.org/10.1016/j.supflu.2011.07.018

Triyana, N.R.S. 2014. PengaruhEkstrakBuah Nanas (Ananas comosus (L). Merr) dan Lama Perendaman Terhadap Kadar Kafein dan Performa padaBiji Kop Robusta (Coffea robusta Lindl. Ex de Will). Skripsi. JurusanBiologi, Fakultas Sainsdan Matematika, Universitas Diponegoro Semarang.

Wang, Y., \& Ho, C. T. (2009). Polyphenolic chemistry of tea and coffee: a century of progress. Journal of agricultural and food chemistry, 57(18), 8109-8114. https://doi.org/10.1021/jf804025c

Wardani, A. K., \& Nindita, L. O. (2012). Purifikasi dan karakterisasi protease dari bakteri hasil isolasi dari whey tahu. Jurnal Teknologi Pertanian, 13(3), 149-156. Widyotomo, S. 2012. Optimasi Suhu Dan Konsentrasi Pelarut Dalam DekafeinasiBiji Kopi Menggunakan Response Surface Methodology. Pelita Perkebunan, 28(3), 184-200.

Widyotomo, S., Mulato, S., Purwadaria, H. K., \& Syarief, A. M. (2009). Decaffeination process characteristic of Robusta coffee in single column reactor using ethyl acetate solvent. Pelita Perkebunan (a Coffee and Cocoa Research Journal), 25(2).

Widyotomo, S., Purwadaria, H. K., \& Ismayadi, C. (2012). Peningkatan mutu dan nilai tambah kopi melalui pengembangan proses fermentasi dan dekafeinasi. In Prosiding Seminar Hasil Penelitian Insentif Riset. Kementerian Riset dan Teknologi.

Widyotomo, S., Syarief, A.M and Purwadaria, H.K. 2011. Pengembangan Mode Matematik Laju Penurunan Kafein dalam Biji Kopi dengan Metode Pengurasan Pelita Perkebunan 27: 109-129.

Yulia, R., Adnan, A. Z., \& Putra, D. P. (2016). Analisis Kadar Kofein Kopi Luwak Dengan Variasi Jenis Kopi, Spesies Luwak Dan Cara Pengolahan Dengan Metoda TlC Scanner..Jurnal Sains Farmasi \& Klinis,2(2), 171-175. 